\title{
Aurora A overexpression and pVHL reduced expression are correlated with a bad kidney cancer prognosis
}

\author{
Imen Ferchichia, ${ }^{a}$, Nadia Kourda ${ }^{\mathrm{b}}$, Samia Sassic ${ }^{\mathrm{c}}$, Khaled Ben Romdhane ${ }^{\mathrm{c}}$, Sarra Balatgi ${ }^{\mathrm{b}}$, \\ Jean Yves Cremet ${ }^{\mathrm{d}}$, Claude Prigent ${ }^{\mathrm{d}}$ and Amel Benammar Elgaaied ${ }^{\mathrm{a}}$ \\ ${ }^{a}$ Department of Biology, Laboratory of Genetics, Immunology and Human Pathology, Faculty of Sciences of Tunis, \\ Tunis, Tunisia \\ ${ }^{\mathrm{b}}$ Department of Histopathology, Charles Nicolle Hospital, Tunis, Tunisia \\ ${ }^{c}$ Department of Histopathology, The Oncology Institute of Saleh Azaïez, Bab Saadoun, Tunis, Tunisia \\ ${ }^{\mathrm{d}}$ The Institute of Genetics and Development of Rennes, Rennes Cedex, France
}

\begin{abstract}
We investigate the expression and localization of the tumor suppressor protein pVHL as well as the oncoprotein Aurora A kinase in kidney cancer. Both Aurora A kinase and pVHL protein status were evaluated using immunohistochemistry. The Aurora A expression is correlated with the Fuhrman grade and the TNM stage, while the pVHL expression is correlated with the capsule rupture and the TNM stage. Aurora A kinase expression increases in malignant tissue comparing to the non-malignant one. And there is a decrease in pVHL expression from the adjacent healthy tissues to the tumor's ones. The two kinds of opposite tumor profiles display significant distribution difference according to TNM stages. It could be proposed that the absence of Aurora A protein associated with a strong expression of pVHL in clear cells kidney carcinoma are of good prognosis for the disease.
\end{abstract}

Keywords: pVHL, Aurora A, kidney cancer, immunohistochemistry

\section{Introduction}

Renal cell carcinoma (RCC) represents $2-3 \%$ of all adults' malignant diseases. It is the most lethal form of urological cancer: local signs and symptoms when occurring appear at an advanced stage of the tumor and have negative prognostic implications [1]. Generally this disease is asymptomatic and $74 \%$ of renal tumors are discovered incidentally during an ultrasound or an abdominal scan requested for something else.

This cancer has a poor prognosis with a rate of 5 years survival around $15 \%$ [2], because the discovery is often

${ }^{*}$ Corresponding author: Imen Ferchichi, Department of Biology, Laboratory of Genetics, Immunology and Human Pathology, Faculty of Sciences of Tunis, Tunis 1060, Tunisia. Tel.: +216 28100848 ; Fax: +216 71231 401; E-mail: science.biologique@yahoo.fr. at late phase or even metastatic phase (20\% to $30 \%$ ) [3]. The high rate of mortality is due not only to the lack of early warning signs and symptoms, but also to the lack of effective treatments for patients at a late stage cancer. The affected people are often aged between 50 and 70 years old. This cancer is rare in children and young adults [4].

There are several histological subtypes of RCC including clear cell, papillary, chromophobe, and oncocytoma variants. But the clear cell Renal Cell Carcinoma (ccRCC) constitutes the most common and aggressive subtype [1]. Despite an increased detection of small kidney masses with cross-sectional imaging and subsequent removal with surgery, mortality has not decreased. So we need to find more tools to improve understanding and management of this disease. The abro- 
gation of the cell cycle mitotic spindle checkpoint has been involved in the progression of RCC $[5,33]$.

Aurora-A is a crucial protein in cell division and many aberrations are assigned to its dysregulation such as genomic instability, abnormal duplication of the centrosomes and cell transformation. Besides, Aurora A could function as an oncogene through the abnormal regulation of centrosome function and this protein is designated as an essential actor in aneuploidy. Given its important role in the process of cell cycle, its overexpression in several cancers that affect: breast [6], colon [7], esophagus [8], ovary [9] has been reported. The expression of this protein was also studied in the kidney cancer [10-12]. Aurora A is a cell cycle protooncogenic serine/threonine kinase, which orchestrates the proper running of mitosis. It controls the cell entry into mitosis [13], the maturation and separation of centrosomes [14] and the assembly and stability of the mitotic spindle [13]. It participates also in cytokinesis [15]. This centrosomal protein plays a key role in regulating the cell cycle via its interaction with p53 protein, which is a transcription factor and a well-known tumor suppressor, thus, inducing cell cycle arrest or apoptosis of the cell when DNA is damaged $[16,17]$.

Finally, at the end of mitosis Aurora A is ubiquitinated and therefore recognized by the $26 \mathrm{~S}$ proteasome and degraded through the ubiquitin-proteasome pathway APC (Anaphase-Promoting Complex). Aurora A kinase is induced by inactivation of pVHL, a tumor suppressor protein [18].

Inactivation of the Von Hippel Lindau (VHL) tumor suppressor gene $[19,20]$ is an early, causal event in the development of clear cell renal cell carcinomas and is common in both hereditary and nonhereditary forms. VHL is the main inactivated gene in ccRCC, with mutations detected in 40-80\% of ccRCC patients [21-25].

The pVHL protein has several functions, the best documented of these functions relates to its role as the substrate-recognition component of multisubunit ubiquitin ligase complex that also contains elongin $\mathrm{B}$, elongin $\mathrm{C}$, cullin 2, and rbx1 [26]. This E3 ligase is involved in the ubiquitin proteasome pathway to degrade the endogenous proteins: the major proteolytic system in the eukaryotic cell. This tumor suppressor protein controls also the cell cycle exit [27,28] participates in the assembly and stability of the mitotic spindle [29, 30] fibronectin binding, and extracellular matrix assembly [26] and it is involved in the activity of centrosomes [31].

The pVHL protein plays a role in chromosome stability [27] and its absence increases aneuploidy. More- over it's involved in the stabilization of the p53 protein, pVHL directly associates and positively regulates the tumor suppressor p53 by inhibiting Mdm2-mediated ubiquitination, Thus pVHL appears to play a crucial role in tumor suppression by participating actively as a component of p53 transactivation complex during DNA damage response, and therefore playing an important role in cell cycle regulation [27] and regulating the tumor growth and cytokinesis [32,33].

The protein $\mathrm{pVHL}$ is present in the cell under three isoforms as following: The isoform 1contains exons 1 , 2 and 3, it encloses 213 amino acid (AA), has as molecular weight of $30 \mathrm{kDa}$ VHL30 [34] and resides mainly in the cytoplasm [30]; the isoform 2 contains only exon 1 and 3 corresponding to a protein with $173 \mathrm{AA}$ and a molecular weight of about $24 \mathrm{KDa}$; The isoform 3 contains 161 AA with a size of $19 \mathrm{kD}$, it was formed as a result of internal translational initiation at an in-frame start codon (ATG) at codon 54 [35]. VHL19 resides primarily in the nucleus [30].

The expression status of tumor suppressor pVHL has been studied in several cancers including ovarian and uterine cancer ones [45], the colorectal cancer and liver metastases [36], as well as in the chondrosarcoma [37]. The expression of this protein was also studied in the kidney [38-41].

Recent studies showed a specific interaction between the oncoprotein Aurora A and the tumor suppressor protein $\mathrm{pVHL}$. These studies included three parts and started with a study in bioinformatics where the interaction 'in silico' was predicted with strong probability, and then an 'in vitro' test using a recombinant protein was done and confirmed this interaction. Finally an 'in vivo' study with endogenous proteins on cell cultures comes to consolidate this hypothesis $[47,48]$.

In the present paper, we investigate the expression of Aurora A kinase and pVHL protein in kidney tumors of CCRCC subtype according to clinical and anatomopathological statuses.

\section{Material and methods}

\subsection{Clinical tissue sample}

79 archival paraffin-embedded tumor sections were collected from the Pathology department in Charles Nicolle Hospital-Tunis. They were obtained from patients who underwent surgery with pathologically confirmed kidney cancer: clear renal cell carcinoma, admitted to the Department of Urology between 2001 and 
Table 1

Patient characteristics $(n=79)$

\begin{tabular}{|c|c|}
\hline Characteristic & Number of patients $(\%)$ \\
\hline \multicolumn{2}{|l|}{ Age (years) } \\
\hline Median & 60 \\
\hline Range & $36-87$ \\
\hline \multicolumn{2}{|l|}{ Sexe } \\
\hline Male & 42 \\
\hline Female & 37 \\
\hline \multicolumn{2}{|l|}{ Tumor Size } \\
\hline$\leqslant 70 \mathrm{MM}$ & 44 \\
\hline$>70 \mathrm{MM}$ & 34 \\
\hline Unknown & 1 \\
\hline \multicolumn{2}{|c|}{ Partial or complet nephrectomy } \\
\hline Partial & 9 \\
\hline Complete & 69 \\
\hline Unknown & 1 \\
\hline \multicolumn{2}{|c|}{ Right or left kidney } \\
\hline Right & 32 \\
\hline Left & 43 \\
\hline Unknown & 4 \\
\hline \multicolumn{2}{|c|}{ Renal capsule rupture } \\
\hline Yes & 20 \\
\hline No & 57 \\
\hline Unknown & 2 \\
\hline \multicolumn{2}{|l|}{ Fuhrman Grade } \\
\hline I & 27 \\
\hline II & 35 \\
\hline III & 14 \\
\hline IV & 3 \\
\hline \multicolumn{2}{|l|}{ TNM stage } \\
\hline $\mathrm{T} 1$ & 37 \\
\hline $\mathrm{T} 2$ & 20 \\
\hline $\mathrm{T} 3$ & 20 \\
\hline Unknown & 2 \\
\hline
\end{tabular}

2010. The following clinical data were collected: age, gender, histological subtype, Fuhrman grade, tumor size, status of the renal capsule and the TNM classification stage. The patients' characteristics are shown in Table 1. The study protocol was approved by the hospital head of the histopathology department.

\subsection{Antibodies}

For Aurora A protein detection we used a mouse monoclonal antibody (clone 35c1, Sigma) which was developed against the non-catalytic $\mathrm{N}$-terminal domain of the kinase. This clone was tested at the UMR6061 in the Institute of Genetics and Development of Rennes, France [42]. For pVHL protein revealing we used a mouse monoclonal anti-Von Hippel Lindau protein (3F391/Ig33) from Novus Biologicals, Inc.

\subsection{Immunohistochemical staining}

Sections of thick $3 \mu \mathrm{m}$ were prepared for each case and stained with Hematoxylin eosin (H\&E) intended for histological examination.

We proceeded to the review of slides and to their classification before we begin our experimentation on tumors initially classified as clear cell carcinomas according to ancient criteria. In fact new identities: renal carcinoma associated with a translocation MITF/TFE, clear cell papillary carcinoma, and carcinoma associated with polycystic disease have been excluded from this study [43].

Briefly, we deparaffinized sections in xylene and we rehydrated them through graded alcohol, then we used a Novolink polymer detection system (RE7150-K, Leica, TN) as recommended in the instruction manual. The slides were incubated with the primary antibody against Aurora A at 1:50 or pVHL at 1:100 overnight in a humidity tray. On the one hand, a positive control was included in each batch: for Aurora A antibody, a slid of colorectal carcinoma known to overexpress the autologous antigen and for pVHL antibody, a slid of healthy kidney which normally expresses this protein were used (Figs 1A, C). On the other hand, a negative control was performed by omitting the primary antibody and as expected, it did not produce any visible background staining (Figs 1B, D).

The evaluation used for intensity of staining and subcellular localization was performed in a blinded manner. The intensity of staining was scored as absent (= $0)$, weak $(=1)$, moderate $(=2)$, or strong $(=3)$ (Figs 2 and 3).

\subsection{Statistical analysis}

The analysis of the results involving the expression of both proteins together with the various histological and clinical parameters were realized, using the chisquare performed with the program Statistical Package for Social Sciences (SPSS 13.0). We considered that results were statistically significant when $p$ values were $<0.05$, asterisks $\left({ }^{*}\right)$ indicates $p<0.05$ and $\left(^{* *}\right)$ indicates $p<0.01$.

\section{Results}

In the 79 studied samples for Aurora A in tumoral tissue, 35 contain a non tumoral one. Only 36 malignant 
Table 2

Aurora A and pVHL intensity and location in different tissues

\begin{tabular}{lccccc}
\hline \multirow{2}{*}{ Intensity } & \multicolumn{2}{c}{ Aurora A } & & \multicolumn{2}{c}{$\mathrm{pVHL}$} \\
\cline { 2 - 3 } \cline { 5 - 6 } & $\begin{array}{c}\text { Non malignant } \\
\text { tissue }\end{array}$ & $\begin{array}{c}\text { Malignant } \\
\text { tissue }\end{array}$ & & $\begin{array}{c}\text { Non malignant } \\
\text { tissue }\end{array}$ & $\begin{array}{c}\text { Malignant } \\
\text { tissue }\end{array}$ \\
\hline 0 & 25 & 36 & & 0 & 0 \\
1 & 7 & 9 & & 2 & 6 \\
2 & 3 & 7 & & 8 & 17 \\
3 & 0 & 27 & & 12 & 13 \\
Location & 3 & 36 & & 20 & 26 \\
$\quad$ Cytoplasmic & 7 & 4 & & 2 & 10 \\
$\quad$ Nuclear and cytoplasmic & & 3 & & 0 & 0 \\
$\quad$ Nuclear & 0 & & & & \\
\hline
\end{tabular}

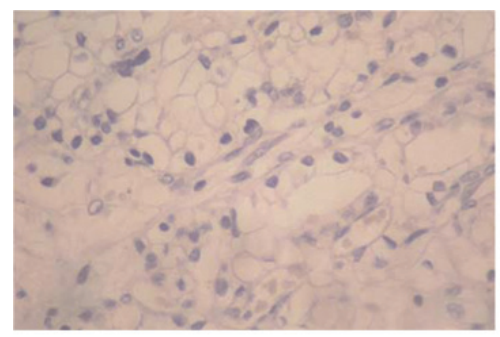

A

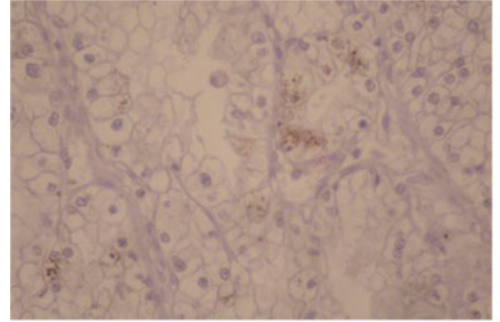

C

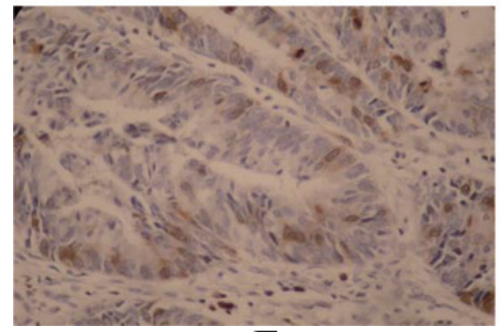

E

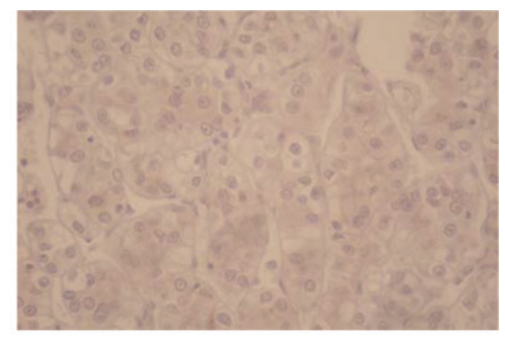

$\mathrm{B}$

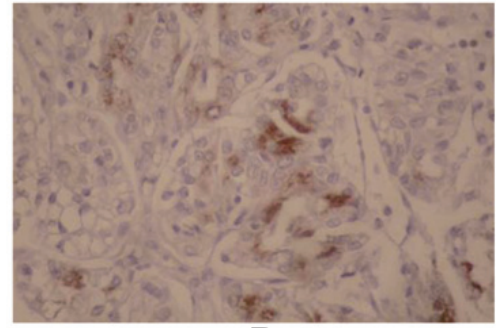

D

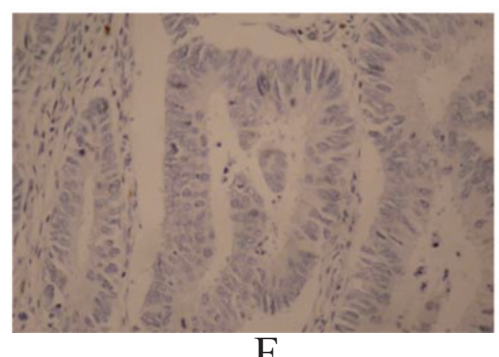

F

Fig. 1. Aurora A immunostaining in human tissue (x400). Brown color indicates antibody binding and intensity of staining. A, B, C and D: Immunostaining of malignant kidney tissue: (A): 0 negative staining, $(\mathrm{B}):+1$ weak positive staining, $(\mathrm{C}):+2$ moderate positive staining, $(\mathrm{D}):+$ 3 strong positive staining. E and F: Immunostaining of colorectal carcinoma (x400): (E): with anti-Aurora A antibody: positive control, (F): without anti-Aurora A antibody: négative control. (Colours are visible in the online version of the article; http://dx.doi.org/10.3233/DMA-2012-00942)

tissues were evaluated for pVHL expression, 22 among them contain a non tumoral tissue.

Using the specific antibody to the Aurora A kinase, the expression of these proteins is investigated by immunohistochemistry on kidney tissue. Usually, Aurora A is absent in non- mitotic normal cells, its expression takes place only during mitosis. When it is expressed in non-mitotic cells the oncoprotein is considered to be overexpressed. Accordingly, Aurora A is overexpressed in $43(54.5 \%)$ of 79 kidney malignant tissues and in $10(26.5 \%)$ of 35 non-malignant adjacent tissues. The modification of protein expression between the non-malignant tissue and the malignant one is supported by significant $p$ value 0.01 (Table 2). This ex- 


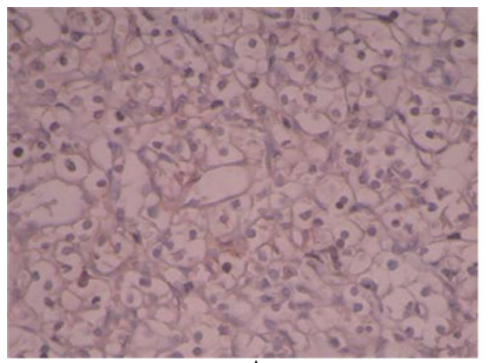

A

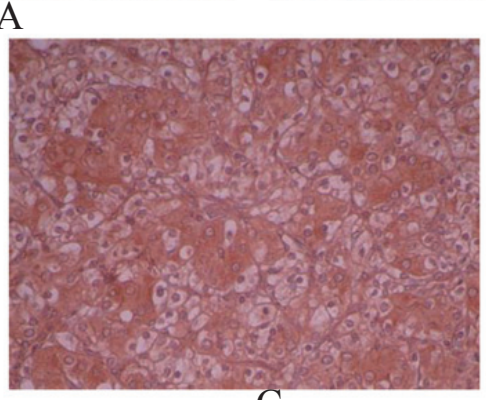

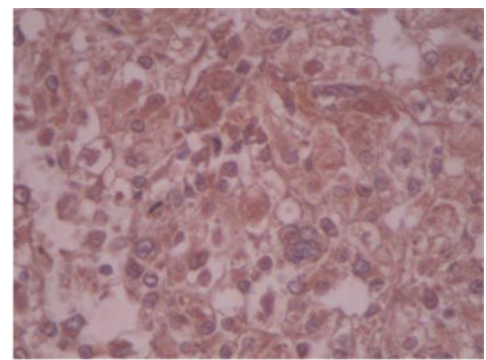

B

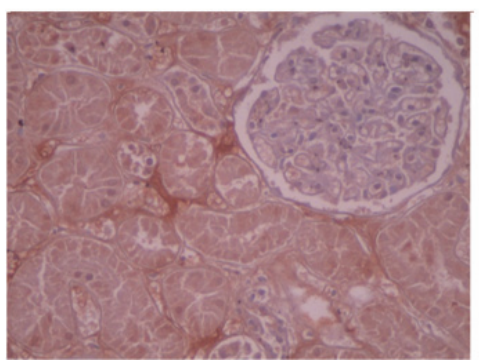

D

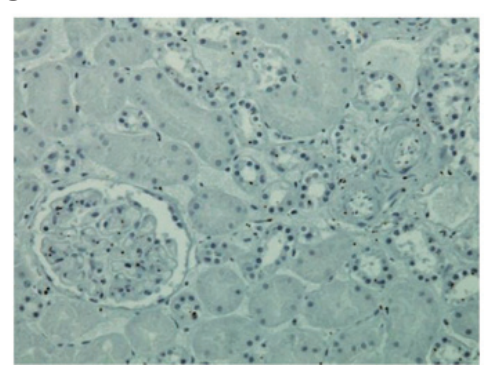

$\mathrm{E}$

Fig. 2. pVHL protein immunostaining in human tissue (x400). Brown color indicates antibody binding and intensity of staining. A, B and C: Immunostaining of malignant kidney tissue $(x 400):(A):+1$ weak positive staining, $(B):+2$ moderate positive staining, $(C):+3$ strong positive staining. D and E: Immunostaining of healthy kidney tissue (x400): (D): with anti-pVHL antibody: positive control, (E): without anti-pVHL antibody: négative control. (Colours are visible in the online version of the article; http://dx.doi.org/10.3233/DMA-2012-00942)

pression has been classified into four levels: $0,1,2$ and 3 ; the level 0 corresponding to the absence of the protein expression, level 1 corresponding to weak expression, the level 2 corresponding to moderate expression and the level 3 corresponding to strong expression.

In non-malignant tissue, when Aurora A is overexpressed, it does not reach the level 3 of expression in the tissue. On the other side, $62.8 \%$ of malignant tissue expressing Aurora A display high intensity labeling $27 / 43$ at level 3. This difference in high level expression between malignant and normal adjacent tissue is significant with $p=0.0003^{* *}$ (Table 2).

When Aurora-A is overexpressed we record the location of the protein. In malignant tissue Aurora A is $83.7 \%$ (36) cytoplasmic, $9.3 \%$ (4) both nuclear and cytoplasmic and $7 \%$ (3) with only nuclear localization. In adjacent non-malignant tissue the distribution of the Aurora A protein is as follows: $30 \%$ (3) cytoplasmic and $70 \%$ (7) both nuclear and cytoplasmic. This difference in location between the non-tumor tissue and tumor one is supported by a significant $p$-value of $0.001^{* *}$ (Table 2) with a great excess of cytoplasmic location in tumor tissue.

The expression of Aurora A kinase in tumor tissue is correlated with the Fuhrman grade with $p$ value of $0.003^{*}$ (Table 3). The expression of Aurora A kinase in tumor tissue is also correlated with the TNM Classification of Malignant Tumours $p=0.008^{* *}$ (Table 3).

Using autologous antibody, the tumor suppressor protein pVHL expression is also investigated by IHC in 36 biopsies. In both neighboring healthy tissue and tumoral tissues, the pVHL is always expressed however with some differences in the level and location. In malignant kidney tissue $16.7 \%$ (6) display a weak intensity, $47.2 \%$ (17) intermediate intensity and 36.1\% (13) show a high one. Contrariwise, in non-malignant 
Table 3

Aurora A and pVHL expression with grade and stage

\begin{tabular}{|c|c|c|c|c|c|}
\hline \multirow[b]{2}{*}{ Aurora A intensity } & \multicolumn{5}{|c|}{ Fuhrman grade } \\
\hline & I & II & III & IV & $p=0.003$ \\
\hline 0 & 14 & 11 & 9 & 2 & \\
\hline 1 & 5 & 1 & 2 & 1 & \\
\hline 2 & 1 & 5 & 1 & 0 & \\
\hline \multirow[t]{2}{*}{3} & 7 & 18 & 2 & 0 & \\
\hline & \multicolumn{5}{|c|}{ TNM stage } \\
\hline Aurora A intensity & $\mathrm{T} 1$ & $\mathrm{~T} 2$ & T3 & \multicolumn{2}{|c|}{$p=0.008$} \\
\hline 0 & 15 & 12 & 8 & & \\
\hline 1 & 6 & 1 & 2 & & \\
\hline 2 & 1 & 0 & 6 & & \\
\hline 3 & 15 & 7 & 4 & & \\
\hline \multirow[t]{2}{*}{ Unknown } & 2 & & & & \\
\hline & \multicolumn{5}{|c|}{ Fuhrman grade } \\
\hline pVHL intensity & I & II & III & IV & $p=0.054$ \\
\hline 1 & 2 & 3 & 1 & 0 & \\
\hline 2 & 6 & 7 & 1 & 3 & \\
\hline \multirow[t]{2}{*}{3} & 3 & 4 & 6 & 0 & \\
\hline & \multicolumn{5}{|c|}{ TNM stage } \\
\hline pVHL intensity & $\mathrm{T} 1$ & $\mathrm{~T} 2$ & T3 & $p=$ & .026 \\
\hline 1 & 2 & 1 & 3 & & \\
\hline 2 & 5 & 3 & 9 & & \\
\hline 3 & 5 & 6 & 1 & & \\
\hline Unknown & 1 & & & & \\
\hline
\end{tabular}

tissue distribution is as following: $9.1 \%$ (2) with low intensity, $36.4 \%$ (8) with moderate intensity and $54.5 \%$ (12) with strong intensity. The difference in protein expression between adjacent healthy and tumor kidney tissues is supported by a $p$ value equal to 0.01 (Table 2).

The Von Hippel Lindau protein exhibits a difference in location between tumor tissue and healthy adjacent tissue. Indeed in the tumor tissue, this expression is often observed at a cytoplasmic level $72.2 \%$ (26 of 36), whereas in healthy adjacent tissue this expression is mainly $90.9 \%$ (20 of 22) cytoplasmic. The difference between the two tissues is not significant (Table 2). However, it seems that pVHL is also expressed at a nuclear level along with cytoplasmic location in $27 \%$ of tumor tissues whereas only $10 \%$ of healthy tissues display such expression profile.

The expression of $\mathrm{pVHL}$ in tumoral tissue according to the grade of Furman is described in Table 3. This expression seems to be similar for the different grades. The decrease of $\mathrm{pVHL}$ protein expression in tumor tissue is correlated with the renal capsule rupture ( $p$ value $=0.027^{*}$ ) as seen in Table 3 . It's also correlated with the advanced T3 stage according to TNM Classification $p=0.002^{*}$ (Table 3).

The expression of Aurora A and pVHL does not significantly vary according to age, sex and tumor size.

Considering both markers, the tumor suppressor protein pVHL strong expression associated to a weak ex- pression of the oncoprotein Aurora A could be regarded as the best prognosis profile and is indeed shown to be the most frequent in T1 stage. On the contrary, the over expression of Aura A and pVHL decrease could be considered as bad prognosis criteria. According to TNM classification, we found that such tumor profiles are frequent in T3 stage. The two kinds of opposite tumor profiles display significant distribution difference according to stages with $p$ value of $0.024^{*}$.

\section{Discussion}

In this study, evidence has been provided for an overexpression of the oncoprotein Aurora A kinase in tumoral kidney cancer tissue, and thus confirming the previous studies [10-12].

When it was available, we also interestingly noted an overexpression of the protein in normal adjacent tissue up to $26.5 \%$, suggesting that this could be an early event in tumor genesis $[11,44]$.

Our comparative study of the expression of this protein between tumor and healthy adjacent tissue pinpoint the change of expression in the progression from the healthy to tumor status and in agreement with the description of the kinase as being an oncoprotein.

The strong expression of the Aurora A protein level qualified by an expression equal to 3 , is obvious in more than the half of the analyzed tumoral tissues, while in the healthy tissue such expression level is never reached; which is consistent with the known role of this protein.

Protein kinase Aurora A expression is predominantly cytoplasmic, which is in agreement with previous studies [6-8,44]. While in normal tissue, such expression was mainly both nuclear and cytoplasmic. This difference in protein location needs to be better investigated and explained according to its functions and to its altered structure and/or dysregulation in tumor cells.

The $\mathrm{pVHL}$ protein expression was positive in $100 \%$ of the studied tissues: tumor as well as adjacent healthy tissue, which is in accordance with the studies done [40, $41,45]$. An apparent decrease was recorded in the expression level of the protein $\mathrm{pVHL}$ from healthy to malignant tissues which is in agreement with the main function of the protein as a tumor suppressor and with a previous study of Horng 2003 [40].

Lin 2008, Horng 2003 and Corless 1997 [40,41,45] found that the expression of the pVHL protein is cytoplasmic in $100 \%$ of the studied tissues, while in our work, the staining was chiefly cytoplasmic in addition 
to mixed nuclear and cytoplasmic staining. The antibody used in our work, recognizes isoform1 (major form) and isoform 2 of pVHL. The major form is both cytoplasmic and nuclear [46]. In their respective work, Lin 2008, Horng 2003 and Corless 1997 [40,41,45] used antibodies expecting to bind all isoforms and have recorded only the cytoplasmic presence of the protein.

Our work is in agreement with that of scharmal 2003 [39], and brings to light, for the first time, a link between pVHL protein expression and the grade of Furhman, TNM classification and the renal capsule rupture, for which statistically significant associations exist.

We suggest that the pVHL protein strong expression protects against high grade and stage, but since we have no indication about endogenous VHL gene mutations nor concerning their effects on VHL protein stability, this remains a mere supposition. There were a statistically significant association between Aurora A protein overexpression with the high grade of Furhman [11] and high stage TNM classification.

Indeed the pVHL protein staining is uniform while the Aurora A protein's is not. In healthy tissue, the pVHL protein expression is ubiquitous, whereas the Aurora A expression takes place only when the cell is in division, which may partly explain the heterogeneity of expression in malignant tissue. Altogether, the expression levels of the oncoprotein Aurora A and tumor suppressor pVHL correlate in an opposite manner and one has to better investigate to which extent a high level of Aurora A expression associated to a reduction in $\mathrm{pVHL}$ expression could be considered as a molecular signature of a high TNM stage and of a bad prognosis. Considering, Aurora A /pVHL interaction $[47,48]$, it could be assumed that the decrease of pVHL could lead or at least participate to Aurora A overexpression [18]. Based on such results and on the observations of the present paper, it could be proposed that absence of Aurora A protein associated to a strong expression of $\mathrm{pVHL}$ in clear cells kidney carcinoma are of good prognosis for the disease.

\section{Acknowledgements}

The research was supported in part by Tunisian State Secretariat for Research and Technology.

\section{References}

[1] Rini BI, Campbell SC, Escudier B. Renal cell carcinoma, Lancet 373 (2009), 1119-1132.
[2] Motzer R, Bander N, Nanus D. Renal cell carcinoma, Medical Prog 335 (1996), 865-875.

[3] Itsumi M, Tatsugami K. Immunotherapy for renal cell carcinoma, Clin Dev Immunol (2010), 284581.

[4] Hollenbeak CS, Nikkel LE, Schaefer EW, Alemao E, Ghahramani N, Raman JD. Determinants of medicare all-cause costs among elderly patients with renal cell carcinoma, J Manag Care Pharm 17(8) (2011), 610-620.

[5] Thoma CR, Toso A, Meraldi P, Krek W. Double-trouble in mitosis caused by von Hippel-Lindau tumor-suppressor protein inactivation. Cell Cycle 8(22) (2009), 3619-3620.

[6] Nadler Y, Camp RL, Schwartz C, Rimm DL, Kluger HM, Kluger Y. Expression of Aurora A (but not Aurora B) is predictive of survival in breast cancer, Clin Cancer Res 14(14) (2008), 4455-4462.

[7] Cammareri P, Scopelliti A, Todaro M, Eterno V, Francescangeli F, Moyer MP, Agrusa A, Dieli F, Zeuner A, Stassi G. Aurora-A is essential for the tumorigenic capacity and chemoresistance of colorectal cancer stem cells, Cancer Res 70(11) (2010), 4655-4665.

[8] Rugge M, Fassan M, Zaninotto G, Pizzi M, Giacomelli L, Battaglia G, Rizzetto C, Parente P, Ancona E. Aurora kinase A in Barrett's carcinogenesis, Hum Pathol 41(10) (2010), 13801386.

[9] Lassus H, Staff S, Leminen A, Isola J, Butzow R. Aurora-A overexpression and aneuploidy predict poor outcome in serous ovarian carcinoma, Gynecol Oncol 120(1) (2011), 11-17.

[10] Ehara H, Yokoi S, Tamaki M, Nishino Y, Takahashi Y, Deguchi T, Kimura M, Yoshioka T, Okano Y. Expression of mitotic Aurora/Ipl1p-related kinases in renal cell carcinomas: an immunohistochemical study, Urol Res 31(6) (2003), 382-386.

[11] Kurahashi T, Miyake H, Hara I, Fujisawa M. Significance of Aurora-A expression in renal cell carcinoma, Urologic Oncology: Seminars and Original Investigations 25 (2007), 128133.

[12] Mathieu R, Patard JJ, Stock N, Rioux-Leclercq N, Guillé F, Fergelot P, Bensalah K. Study of the expression of Aurora kinases in renal cell carcinoma, Prog Urol 20(13) (2010), 1200-1205.

[13] Cowley DO, Rivera-Pérez JA, Schliekelman M, He YJ, Oliver TG, Lu L, O’Quinn R, Salmon ED, Magnuson T, Van Dyke T. Aurora-A kinase is essential for bipolar spindle formation and early development, Mol Cell Biol 29(4) (2009), 1059-1071.

[14] Meraldi P, Honda R, Nigg EA. Aurora-A overexpression reveals tetraploidization as a major route to centrosome amplification in p53-/- cells, Embo J 21 (2002), 483-492.

[15] Fu J, Bian M, Jiang Q, Zhang C. Roles of Aurora kinases in mitosis and tumorigenesis, Mol Cancer Res 5(1) (2007), 1-10.

[16] Katayama H, Sasai K, Kawai H, Yuan ZM, Bondaruk J, Suzuki F, Fujii S, Arlinghaus RB, Czerniak BA, Sen S. Phosphorylation by aurora kinase A induces Mdm2-mediated destabilizationand inhibition of p53, Nat Genet 36 (2004), 55-62.

[17] Liu Q, Kaneko S, Yang L, Feldman RI, Nicosia SV, Chen J, Cheng JQ. Aurora-A abrogation of p53 DNA binding and transactivation activity by phosphorylation of serine $215, \mathrm{~J}$ Biol Chem 279 (2004), 52175-52182.

[18] Xu J, Li H, Wang B, Xu Y, Yang J, Zhang X, Harten SK, Shukla D, Maxwell PH, Pei D, Esteban MA. VHL inactivation induces HEF1 and Aurora kinase A, J Am Soc Nephrol 21(12) (2010), 2041-2046.

[19] Latif F, Tory K, Gnarra J, Yao M, Duh FM, Orcutt ML, et al. Identification of the von Hippel-Lindau disease tumor suppressor gene, Science 260 (1993), 1317-1320. 
[20] Kaelin WG Jr. The von Hippel-Lindau tumor suppressor protein and clear cell renal carcinoma, Clin Cancer Res 13 (2007), 680-684

[21] Banks RE, Tirukonda P, Taylor C, Hornigold N, Astuti D, Cohen D, Maher ER, Stanley AJ, Harnden P, Joyce A, Knowles M, Selby PJ. Genetic and epigenetic analysis of von HippelLindau (VHL) gene alterations and relationship with clinical variables in sporadic renal cancer, Cancer Res 66 (2006), 2000-2011.

[22] Gnarra JR, Tory K, Weng Y, Schmidt L, Wei MH, Li H, et al. Mutations of the VHL tumour suppressor gene in renal carcinoma, Nat Genet 7 (1994), 85-90.

[23] Brauch H, Weirich G, Brieger J, Glavac D, Rödl H, Eichinger M, Feurer M, Weidt E, Puranakanitstha C, Neuhaus C, Pomer S, Brenner W, Schirmacher P, Störkel S, Rotter M, Masera A, Gugeler N, Decker HJ. VHL alterations in human clear cell renal cell carcinoma: association with advanced tumor stage and a novel hot spot mutation, Cancer Res 60 (2000), 1942-1948.

[24] Nickerson ML, Jaeger E, Shi Y, Durocher JA, Mahurkar S, Zaridze D, Matveev V, Janout V, Kollarova H, Bencko V, Navratilova M, Szeszenia-Dabrowska N, Mates D, Mukeria A, Holcatova I, Schmidt LS, Toro JR, Karami S, Hung R, Gerard GF, Linehan WM, Merino M, Zbar B, Boffetta P, Brennan P, Rothman N, Chow WH, Waldman FM, Moore LE. Improved identification of von Hippel-Lindau gene alterations in clear cell renal tumors, Clin Cancer Res 14 (2008), 4726-4734.

[25] Young AC, Craven RA, Cohen D, Taylor C, Booth C, Harnden P, Cairns DA, Astuti D, Gregory W, Maher ER, Knowles MA, Joyce A, Selby PJ, Banks RE. Analysis of VHL gene alterations and their relationship to clinical parameters in sporadic conventional renal cell carcinoma, Clin Cancer Res 15 (2009), 7582-7592.

[26] Ohh M, Yauch RL, Lonergan KM, Whaley JM, StemmerRachamimov AO, Louis DN, Gavin BJ, Kley N, Kaelin WG Jr, Iliopoulos O. The Von Hippel-Lindau tumor suppressor protein is required for proper assembly of an extracellular fibronectin matrix, Mol Cell 1 (1998), 959-968.

[27] Roe JS, Youn HD. Extra view the positive regulation of $\mathrm{p} 53$ by the tumor suppressor VHL, Cell Cycle 5 (2006), 2054-2056.

[28] Pause A, Lee S, Lonergan KM, Klausner RD. The Von HippelLindau tumor suppressor gene is required for cell cycle exit upon serum withdrawal, Proc Natl Acad Sci USA 95(3) (1998), 993-998.

[29] Lolkema MP, Mehra N, Jorna AS, van Beest M, Giles RH, Voest EE. The von Hippel-Lindau tumor suppressor protein influences microtubule dynamics at the cell periphery, Exp Cell Res 301(2) (2004), 139-146.

[30] Hergovich A, Lisztwan J, Barry R, Ballschmieter P, Krek W. Regulation of microtubule stability by the Von Hippel-Lindau tumour suppressor protein pVHL, Nat Cell Biol 5 (2003), 6470.

[31] Kuehn EW, Walz G, Benzing T. Von hippel-lindau: a tumor suppressor links microtubules to ciliogenesis and cancer development, Cancer Res 67(10) (2007), 4537-4540.

[32] Sinha S, Mondal G, Hwang EJ, Han da W, Dutta SK, Iyer S, Karumanchi SA, Kim KI, Couch FJ, Mukhopadhyay D. Von Hippel-Lindau gene product directs cytokinesis: a new tumor suppressor function, J Cell Sci 124 (2011), 2132-2142.

[33] Thoma CR, Toso A, Gutbrodt KL, Reggi SP, Frew IJ, Schraml
P, Hergovich A, Moch H, Meraldi P, Krek W. VHL loss causes spindle misorientation and chromosome instability, Nat Cell Biol 11(8) (2009), 994-1001.

[34] Kim WY, Kaelin WG. Role of VHL gene mutation in human cancer, J Clin Oncol 22(24) (2004), 4991-5004.

[35] Yuen JSP. Molecular targeted therapy in advanced renal cell carcinoma: a review of its recent past and a glimpse into the near future, Indian J Urol 25 (2009), 427.

[36] Rajaganeshan R, Prasad PJ, Guillou N, Scott G, Poston DG. Jayne Expression patterns of hypoxic markers at the invasive margin of colorectal cancers and liver metastases, Eur J Surg Oncol 35(12) (2009), 1286-1294.

[37] Chen L, Ao X, Ren Q, Wang ZN, Lu C, Xu Y, Jiang L, Luo Y, Xu HM, Zhang XYi. Linkage disequilibrium and haplotype analysis of two single nucleotide polymorphisms in STK15 in Chinese, Yi Chuan Xue Bao 32(4) (2005), 331-336.

[38] Gossage L, Eisen T. Alterations in VHL as potential biomarkers in renal-cell carcinoma, Nat Rev Clin Oncol 7(5) (2010), 277-288.

[39] Schraml P, Hergovich A, Hatz F, Amin MB, Lim SD, Krek W, Mihatsch MJ, Moch H. Relevance of nuclear and cytoplasmic von hippel lindau protein expression for renal carcinoma progression, Am J Pathol 163(3) (2003), 1013-1020.

[40] Horng-Yih Shiao, Forsti A, Egevad L, Anderson LM, Lindblad P, Hemminki K. VHL down-regulation and differential localization as mechanisms in tumorigenesis, Kidney Int 64(5) (2003), 1671-1674

41] Corless CL, Kibel AS, Iliopoulos O, Kaelin WG Jr. Immunostaining of the von Hippel-Lindau gene product in normal and neoplastic human tissues, Hum Pathol 4 (1997), 459-464.

[42] Cremet J Y, Descamps S, Vérité F, Martin A, Prigent C. Preparation and characterization of a human aurora-A kinase monoclonal antibody, Mol Cell Biochem 243 (2003), 123-131.

[43] Ficarra V, Brunelli M, Cheng L, et al. Prognostic and therapeutic impact of the histopathologic definition of parenchymal epithelial renal tumors, Eur Urol 58 (2010), 655-668.

[44] Altaf Dar A, Zaika A, Piazuelo MB, Correa P, Koyama T, Belkhiri A, Washington K, Castells A, Pera M, El-Rifai W. Frequent overexpression of Aurora Kinase A in upper gastrointestinal adenocarcinomas correlates with potent antiapoptotic functions, Cancer 112(8) (2008), 1688-1698.

[45] Lin F, Shi J, Liu H, Zhang J, Zhang PL, Wang HL, Yang $\mathrm{XJ}$, Schuerch C. Immunohistochemical detection of the von Hippel-Lindau gene product (pVHL) in human tissues and tumors: a useful marker for metastatic renal cell carcinoma and clear cell carcinoma of the ovary and uterus, Am J Clin Pathol 129(4) (2008), 592-605.

[46] Iliopoulos O, Ohh M, Kaelin WG Jr. pVHL19 is a biologically active product of the von Hippel-Lindau gene arising from internal translation initiation. Proc Natl Acad Sci USA 95(20) (1998), 11661-11666.

[47] Ferchichi I, Stambouli N, Marrackchi R, Arlot Y, Prigent C, Fadiel A, Odunsi K, Ben Ammar Elgaaied A, Hamza A. Experimental and computational studies indicate specific binding of pVHL protein to Aurora-A kinase, J Phys Chem B 114(3) (2010), 1486-1497.

[48] Ferchichi I, Arlot Y, Prigent C, Benammar Elgaaied A. AuroraA kinase interact with and phosphorylate pVHL, Biologia 67(5) (2012), 1026-1030. 


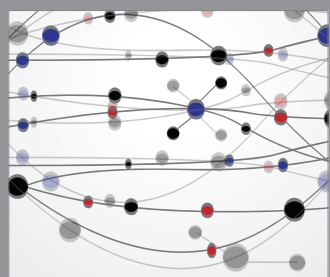

The Scientific World Journal
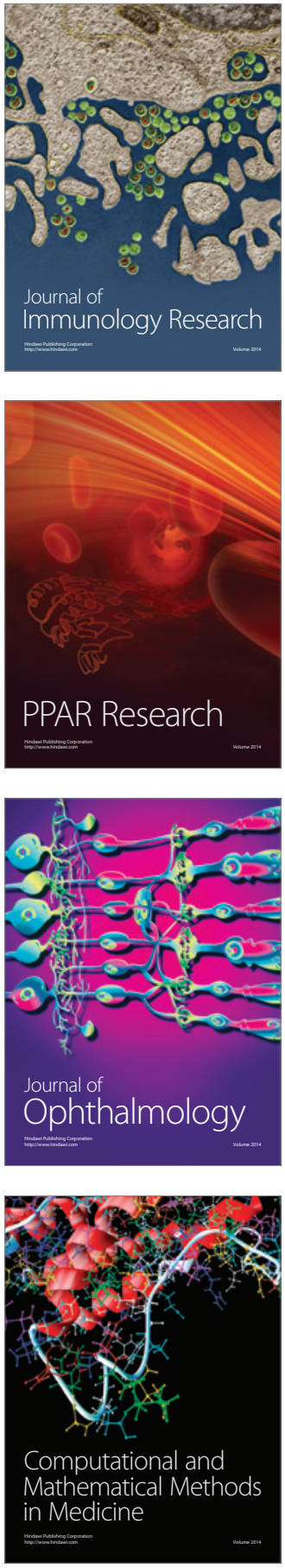

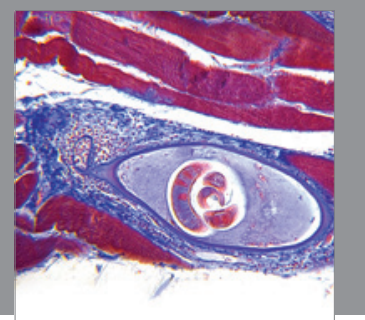

Gastroenterology

Research and Practice
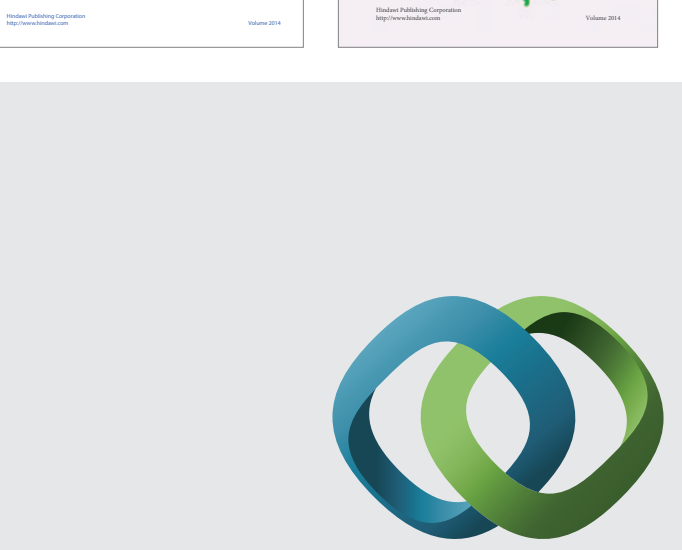

\section{Hindawi}

Submit your manuscripts at

http://www.hindawi.com
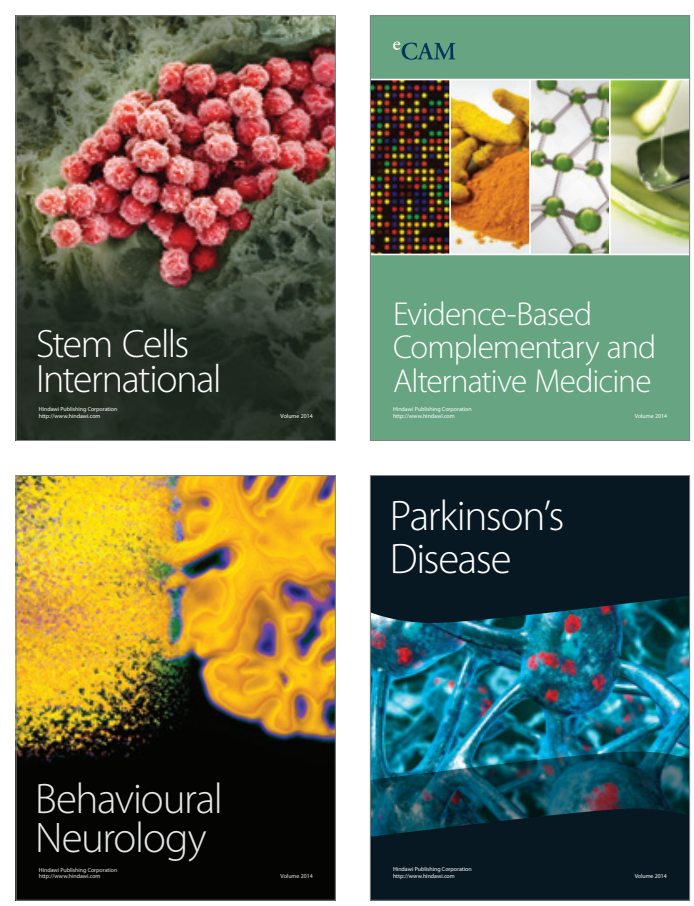

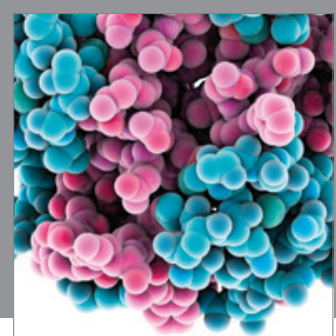

Journal of
Diabetes Research

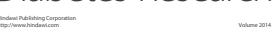

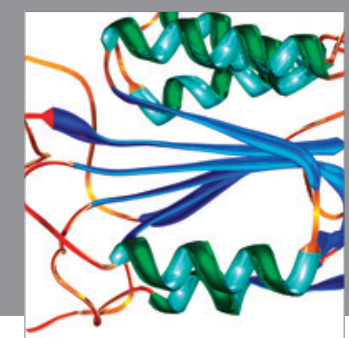

Disease Markers
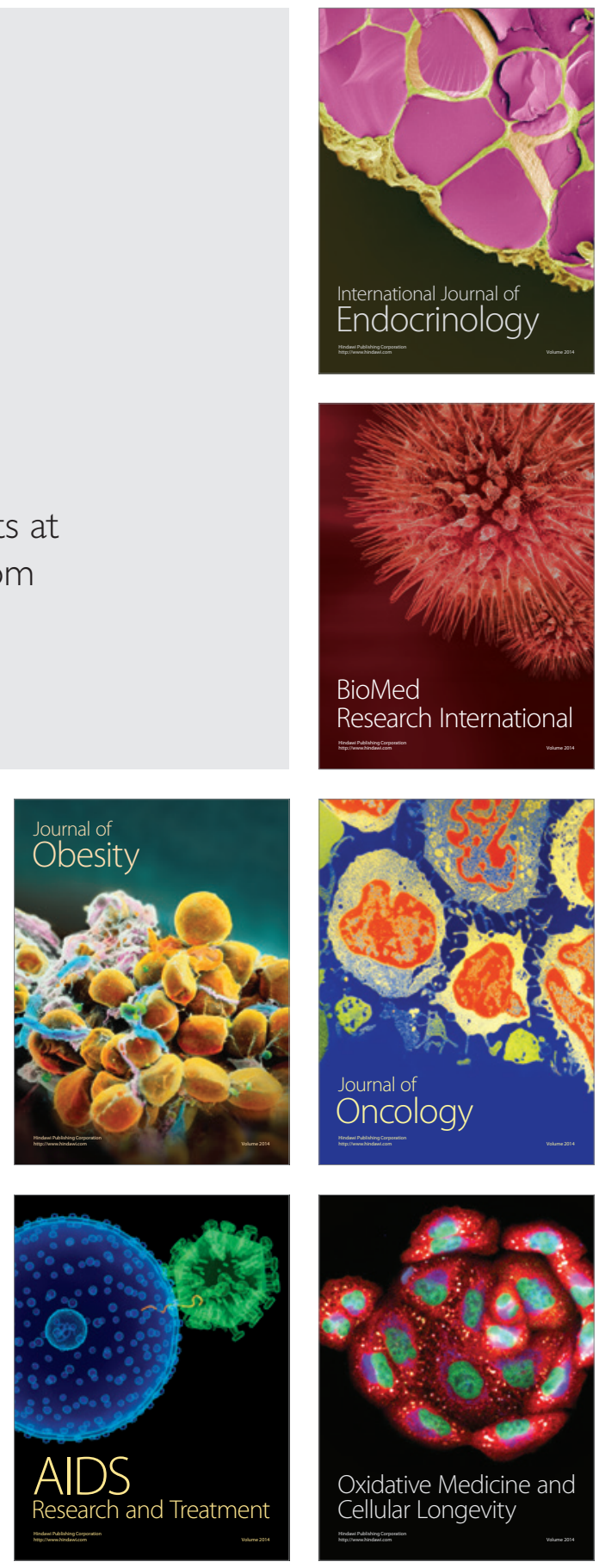